\title{
Organizational Structure and Organizational Justice in Jordanian Commercial Banks: A field study
}

\author{
Dr. Khaled Abdalla Moh'd Al-Tamimi (Corresponding author) \\ Department of Administrative and financial Sciences, Irbid University College \\ Al-Balqa'a Applied University, Jordan \\ E-mail: khaled_tamimi@yahoo.com
}

Received: December 5, 2016

Accepted: December 26, 2016

doi:10.5296/ber.v6i2.10389

URL: http://dx.doi.org/10.5296/ber.v6i2.10389

\begin{abstract}
The aim of this study is to identify organizational structure and organizational justice in Jordanian Commercial banks. The study, after presenting, analyzing and testing hypothesis related to (OS) and (OJ) adopted in Jordanian commercial banks, the study revealed a set of results, among which: 1-organizational structure dimensions have no statically significant difference on employees in the organization, and this is consistent with the concept of the need for achievement of individuals, which the individual does not look forward towards its achievement ,for individuals, and that individual does not seek to satisfy as a priority whether it relates to levels of applying organizational structure dimension either centralization, formality and so on .2- Organizational structure and organizational justice dimensions, when combined together, have no statically significant effect on satisfying workers for independence and power.
\end{abstract}

3- Subject educational qualification has no statistically significant effect.

Keywords: Organizational structure, Organizational justice, Commercial banks, Centralization, Formalization

\section{Introduction}

We can say that the age in which we live is called "organizations age", because wherever a man looks, and where ever goes, he finds himself surrounded with various organizations, however each organization should have and organizational philosophy in its operations management and effectiveness and raising its functional competency, and increasing its possibility to tailor organizational mechanisms and policies in order to achieve its goals, objectives and mission in the society, and the organizational structure is the frame in which all variables related to organizations and their functions, as inside this frame, communication, 
authorities, and responsibilities as well as activities and information exchange are specified, and in short it is the main instrument that organizations cannot survive without it when seeking the achievement of its goals.

Human factor constitutes one of the most important factor in organizational work system , on which the extent to which institution success or failure in realizing their goals is based, and this can be achieved through its performance. As the leadership style of the manager or individual worker behavior, might constitute destruction or construction factors of the organizational work organization, which might require the existence of positive harmony between them in order to enhance both organizational efficiency and effectiveness (Al-Ameri, 2003).

Therefore human behavior and its explanation should receive special and serious attention, as well as its prediction, control and manipulated for the achievement of corporations goal efficiently and effectively (Hareem, 1998).

It was also argued that individual perception of justice is influenced by social and religious values, and one of the most important factors influencing the relationship between managers and employees, is the extent to which one party perception of achieving justice values in that relationship, and from here come the interest in explaining the behavior resulting from the above mentioned relationship and predicting it in work situation and personal exchange relationships (Hammodeh, 1999).

Human and social science specialists recognized the importance of justice principles and values as a basis for distinguished performance of corporations and satisfaction of their workers, however, due to this increased importance, there have been serious attempts to apply social and human justice theories to understand individuals behavior inside organizations and using them as a base to explain various organizational behavior types and manifestations, which in turn led to the rise of organizational justice concept as one of the modern organizational behavior concepts, that attracted many researchers in the field of management, to study it and define its dimensions and implications (Al-Ajmi, 1998).

Its no doubt that organizational justice topic is one of the organizational behavior topics that received great interest due to what it contains of justice and equality values that are considered of organizational and behavioral variables that help in understanding individual behavior at work.

However, organizational justice, which appeared during the 1990s, and became clear and the focus of several managerial studies when using this concept as a base for explaining many of workers organizational behavior forms, given that organizational justice reflects the way by which individuals judge the justice of the style used by the manger in dealing with him on both job and human levels (Al-Maharmeh, 2000).

\section{Significance of the Study}

Man is one of the basic components of organizations, and is the first of these components, also individuals in any organization seek to satisfy their various needs, therefore the 
importance of the current study lies in two sides:

1. Theoretical side, however there are no direct studies before this one, in general, that addressed the organizational structure and organizational justice and workers ability to satisfy their needs in Jordanian commercial banks, so, and for the bet knowledge of the researcher, results of the current study will be a quality addition to economic and administrative sciences library.

2. As for the applied aspect (part), researcher hopes that results and recommendations of the current study, might be a reference for commercial banks to benefit from when modifying organizational structure and organizational justice according to satisfying their workers needs.

Moreover, the current study is the first of its kind regarding examination of organizational structure (OS) on the extent to which workers perceive organizational justice, as (Schminke et al 2000) found that centralization in (OS) negatively affected employees perception of procedural justice and that large organization size ,also, negatively affected employees perception of interactive organizational justice (OJ), however they found no effect of formalization degree in (OS) on (OJ). But we notice that they did not address, in their study, the potential relationship between the degree of centralization in (OS) and interactive justice, and this was a focus of the current study. In addition this study is one of the rare studies, as to the researcher best knowledge, where literature reviews showed the scarcity of this kind of studies in the Arab environment in general and Jordanian one in particular.

\section{Statement of the Problem}

Increasing load in the organizational structure and (OJ) in Jordanian commercial banks have led to conducting the current study which tries to answer the following research questions:

1. What is meant by organizational structure and organizational justice?

2. Do (OS) dimensions including centralization, formalization and organizational size on (OJ), from perspectives of commercial bank employees?

3. Is there a relationship between employees demographics (gender, educational qualification and years of experience) in satisfying their needs in these organizations?

\section{Research Hypothesis}

$\mathbf{H}_{1}$ : no statistically significant relationship in the degree to which $(\mathrm{OJ})$ is practiced in commercial banks due to employees gender, is found.

$\mathbf{H}_{2}$ : No statistically significant relationship in the degree to which (OJ) is practiced in commercial banks from employees perspectives, due to their educational qualification, is found.

$\mathbf{H}_{3}$ : A statistical y significant relationship in the degree to which $(\mathrm{OJ})$ is practiced in commercial banks, from employees perspective, due to their total salary, is found.

$\mathbf{H}_{4}$ : No statistically significant relationship in the degree to which (OJ) is practiced in 
commercial banks, from employees perspective, is found.

H5: A statistically significant relationship in the degree to which (OJ) is practiced in commercial banks, from employees perspective, is found.

\section{Research Objectives}

The current study aimed at investigating organizational structure elements (centralization, and formalization degree), as some theorists argued that there is an inverse relationship between centralization and formalization, while others argued that this relationship is positive (direct). The study also aimed at identifying or investigating the relationship between organization size and employees perceptions of organizational justice (procedural and interactive) from the other hand.

\section{Procedural Definitions}

All independent and dependent variables procedural definitions, for purposes of the current study, will be specified according to what each construct meant in previous researches conducted in the field of organizational structure and organizational justice; These constructs are:

1. Organizational structure: the way through which organizations activities are divided, organized and coordinated.

2. Organizational justice: individuals workers tendency to compare their situation (State) with that of their peers at work.

\section{Study Limitations}

The current study was limited to commercial banks operating in Jordan, where 200 questionnaires were distributed to all employees working in these banks, of which 150 were returned, and 140 valid for statistical analysis.

\section{Literature Review}

Abu Dhaim (2011) conducted a study entitled "the role of human resources management practices in achieving organizational justices: from the standpoints departments heads in Jordanian ministries. The study aimed at identifying the level of organizational justice among department heads in Jordanian ministries, as well as, identifying the effect of demographic factors (gender, age, educational qualifications and work experience) in the relationship between human resources management practice and organizational justice. Results showed that department heads, in Jordanian ministries, enjoyed medium rates of organizational justice, as well as the existence of statistically significant differences between HRM practice of organizational justice, due to their demographic variables (gender, age, educational qualification and work experience).

Alsoud and Sultan (2009) conducted a study entitled. The degree of organizational justice of departments heads and its relationship with organizational loyalty. Results of the study were: (1) increased level of organizational justice among departments heads with increased 
organizational loyalty of faculty members, (2) the existence of positive relationship between department heads practice of organizational justice and organizational commitment due to demographic variables.

Al-Etewi (2007) conducted a study entitled "the effect of organizational justice in contextual performance" in which correlation relationship, effect of performance level between organizational justice elements and contextual performance level of faculty members at administration college in the university of Al-Qadisyah and showed statistically significant correlation between most organizational justice dimensions and contextual performance, as well as a statistically significant influence between procedural and relational justice on contextual performance.

Wadi (2007) study entitled "organizational justice": A field study main results of this study were: (1) and accepted distributed justice due to justice in outcomes received by individuals with (61.9\%), was found, (2) No justice in dealing with $(57.2 \%)$, when executing formal procedures was found, (3) the existence of but weak, organizational justice with (59\%).

Al-khashaly (2006) conducted a study entitled The impact of organizational structure dimensions on organizational knowledge generation: A Field Study of Jordanian Private Hospitals, which aimed at identifying the extent to which organizational structure influences managers needs satisfaction. Among the results of this study is (1) No statistically significant influence of organizational structure components together in meeting or satisfying managers need for achievement, as well as the existence of statistically significant influence of organizational structure components, together, in meeting managers need of belonging, independence and power.

Al-Maitah (2005) conducted a study entitled "the degree to which Jordanian public secondary schools principals practice organizational justice and its relationship with their teachers organizational citizenship behavior. Results showed that relative importance of organizational justice, in general, was medium, result, also showed a strong correlation relationship between organizational justice and loyalty, as well as the existence of statistically significant differences in the degree to which school principals practice organizational justice due to their educational qualification, in favor of masters or above degrees holders, however no statistically significant differences due to subjects gender and experience, were found.

Al- Qatawneh (2003) conducted a study entitled" Influences of organizational justice in organizational commitment", the purpose of which was to identify the influences of organizational justice in organizational commitment of persons working at administrative departments at Kerak, Tafillah and Ma'an Governorates centers. The study population consisted of all employees working at governorate centers under investigation totaling for (2444) male and female subjects within (18) departments. A random sample of (700) employees, males and females, was selected, representing $(28.6 \%)$ of the study population, (631) of which were returned, and (90\%) of the study sample. Following are main results of the study:

1. Subjects perceptions of organizational justice was a moderate degree, with a mean of 
(3.1541).

2. Subjects perceptions of organizational commitment was a moderate degree with a mean of (3.394).

3. A strong and statistically significant correlation relationship between organizational justice and organizational commitment, was found.

4. A statistically significant effect, of organizational justice on organizational commitment, was found.

5. Statistically significant differences between subjects perceptions of organizational justice, due to their demographic variables (experience, salary and age, were found).

6. Statistically significant differences between subjects perceptions of organizational commitment due to their educational qualification, experience and salary, were found.

Al-Thaih (2003) conducted a study entitled "relationship between organizational structure and the extent to which organization justice is perceived" aiming at identifying the relationship between organizational structure components, organizational size and workers perceptions of procedural and interactive organizational justice. Among the main results of this study are the existence of inverse (negative) relationship organizational structure centralization and the extent to which employees perceive procedural and interactive justice. Results also showed positive relationship between formalization degree in the organizational structure and the extent to which employees perception of procedural justice, however the study found no significant relationship between organization size and the extent to which employees perception of both procedural and interactive justice.

Cloquitt (2001) on the dimensionality of Organizational justice: A construct validation of a measure. This study explores the dimensionality of organizational justice and provides evidence of construct validity for a new justice measure. Items for this measure were generated by strictly following the seminal works in the justice literature. The measure was then validated in 2 separate studies. Study 1 occurred in a university setting, and Study 2 occurred in a field setting using employees in an automobile parts manufacturing company. Confirmatory factor analyses supported a 4-factor structure to the measure, with distributive, procedural, interpersonal, and informational justice as distinct dimensions. This solution fit the data significantly better than a 2- or 3-factor solution using larger interactional or procedural dimensions. Structural equation modeling also demonstrated predictive validity for the justice dimensions on important outcomes, including leader evaluation, rule compliance, commitment, and helping behavior.

\section{Research Instrument}

An analytical descriptive approach is used. Secondary information has been obtained from specialized studies and scientific sources, while primary information was generated through a questionnaire. 


\subsection{Instrument Validity}

Validity of the instrument was established by submitting it to six main banks in Irbid city, and are the Housing bank for trade and finance, Arab bank, Cairo Amman bank, Al - Ahli bank, Jordan Kuwait bank, and bank of Jordan, to ensure comprehensively of information covering study objectives and basic topic, and their comments were taken into consideration, and needed changes were made.

\subsection{Instrument Reliability}

To ensure instrument reliability, internal consistency. Coefficient, according to Cronbach alpha, was Calculated, where it is value was (0.94), and was doomed appropriate for purposes of this study.

Study variables:

1. Independent variable: Organizational structure.

2. Dependent variable: Organizational justice.

\subsection{Study Sample}

The following table displays study sample distribution according to demographic variables.

Table 1. Sample distribution by demographics

\begin{tabular}{|l|l|l|l|}
\hline Variable & Categories & Frequency & Percentage $\%$ \\
\hline Gender & Male & 94 & 67.1 \\
\hline Educational & Female & 46 & 32.9 \\
\hline Qualification & Community college diploma & 27 & 19.3 \\
\hline & Others & 100 & 71.4 \\
\hline Total & $<450$ & 13 & 9.3 \\
\hline Salary & 450 to $<650$ & 44 & 31.4 \\
\hline & 650 to $<850$ & 61 & 43.6 \\
\hline & 580 and more & 16 & 11.4 \\
\hline Job nature & Supervisory & 19 & 13.6 \\
\hline & Non Supervisory & 54 & 38.6 \\
\hline Experience Years & Less than 5 & 86 & 61.4 \\
\hline & $5-10$ & 31 & 22.1 \\
\hline & $11-15$ & 45 & 32.1 \\
\hline & More than 15 & 30 & 21.4 \\
\hline & Total & 34 & 24.3 \\
\hline & & 140 & $100 \%$ \\
\hline
\end{tabular}

\subsection{Means Classification}

The following criterion in classifying means degree will be adopted:

Less than $2.5 \quad$ Low degree 
2.5- less than 3.5

3.5 and More
Moderate degree

high degree

Research questions (1) to what degree, organizational justice, is practiced in commercial bank, from employees perspective.

Means and standard deviation of subjects responses were used, in answering this questions and results are shown in table (2).

Table 2. Means and standard deviations of the degree to which organizational justice it eves are practiced from workers perspectives, in beseeching order.

\begin{tabular}{|c|c|c|c|c|c|}
\hline No. & Rank & Item & Mean & S. deviation & Degree \\
\hline 1 & 1 & Manager makes decision without bias & 3.75 & 1.18 & High \\
\hline 2 & 2 & $\begin{array}{l}\text { Manager cares about having opinions of each employee } \\
\text { before making job related decisions }\end{array}$ & 3.31 & 1.04 & Moderate \\
\hline 3 & 3 & $\begin{array}{l}\text { Manager collects concise and precise information before } \\
\text { making job related decisions }\end{array}$ & 3.29 & 1.05 & Moderate \\
\hline 4 & 4 & $\begin{array}{l}\text { Manager collects concise and precise information before } \\
\text { making job related decisions }\end{array}$ & 3.19 & 1.16 & Moderate \\
\hline 5 & 5 & $\begin{array}{l}\text { Managerial decision are applied to all employees with no } \\
\text { exception. }\end{array}$ & 3.16 & 1.09 & Moderate \\
\hline 7 & 5 & $\begin{array}{l}\text { When manager makes a decision relation to my job, he } \\
\text { deals with me with full care and intimacy }\end{array}$ & 3.16 & 1.22 & Moderate \\
\hline 10 & 7 & $\begin{array}{l}\text { When manager makes a decision related to my job he cares } \\
\text { about my interests as employees }\end{array}$ & 3.11 & 1.31 & Moderate \\
\hline 8 & 6 & Manager allows employees to refuse or resist his decisions & 3.06 & 1.21 & Moderate \\
\hline 9 & 11 & $\begin{array}{l}\text { Managers discusses with me results of decisions that might } \\
\text { influence my job }\end{array}$ & 3.05 & 1.26 & Moderate \\
\hline 10 & 9 & $\begin{array}{l}\text { When manager makes a decision related to my job he } \\
\text { frankly discussed the decision with me. }\end{array}$ & 2.99 & 1.27 & Moderate \\
\hline 11 & 17 & $\begin{array}{l}\text { When my direct supervisor makes a decision related to my } \\
\text { job, he explains reasons for taking that decision }\end{array}$ & 2.97 & 1.19 & Moderate \\
\hline 12 & 12 & $\begin{array}{l}\text { Manager explains rationales for decisions related to my } \\
\text { job. }\end{array}$ & 2.94 & 1.17 & Moderate \\
\hline 13 & 8 & $\begin{array}{l}\text { When manager makes decision related to my job, he takes } \\
\text { my personal demands into account }\end{array}$ & 2.9 & 1.23 & Moderate \\
\hline 14 & 14 & $\begin{array}{l}\text { Manager explains to me, in clear manner, any decision } \\
\text { taken regarding my job. }\end{array}$ & 2.69 & 1.29 & Moderate \\
\hline & & Instrument as a whole & 3.11 & 0.50 & Moderate \\
\hline
\end{tabular}

Table (2) shows means and standard deviations of organizational justice terms degree of practice in commercial banks from employees perspectives, where items (1) "Manager makes job decisions in an unbiased style came in the first rank with a mean of (3.75) followed by item (2) "Manager take care to having each employee opinion before making decisions 
related to work (job); with a mean of (3.31), and in the third rank came item no (3) Manager collects and precise information before making job related decision, with a mean $\mathrm{f}$ (3.29) whereas item (14) Manager explains to me, in a cheer manner, any decision taken regarding my job, in the $14^{\text {th }}$ and last rank, with a mean of (2.69), however total instrument mean was (3.11).

Hypothesis one $\left(\mathrm{H}_{1}\right)$, No statistically significant relationship at $(\alpha=0.05)$ level in the degree to which organizational justice in commercial banks from employees perspectives, due to their gender, will be found.

To test this hypothesis, means and standard deviations of the degree to which organizational justice is practiced in commercial banks, from employees perspectives according to their gender, were used, and to identify statistically significant differences between respondents means, test was used, and its results are displayed in table (3) below.

Table 3. T- test results for gender effect on respondents mean evaluations of organizational justice

\begin{tabular}{|l|l|l|l|l|l|l|}
\hline Gender & Number & Mean & S. deviation & T-test value & D.F & Sig. \\
\hline Male & 94 & 3.14 & 0.48 & 1.020 & 13.8 & 0.309 \\
\hline Female & 46 & 3.05 & 0.54 & & & \\
\hline
\end{tabular}

Table (3) showed no statistically significant differences at $(\alpha=0.05)$ level due to subjects gender, meaning that this hypothesis was accepted.

Hypothesis (2) "No statistically significant relationship at $(\alpha=0.05)$ level in the degree to which organizational justice in commercial banks, from employees perspectives, due to subject educational qualification, will be found.

To test this hypothesis, means and standard deviation of the degree to which organizational justice is practiced in commercial banks, from employees perspective, due to subjects educational qualification, results, of these means and standard deviation are shown in table (4).

Table 4. Means and standard deviations of the degree to which organizational justice according to educational qualification

\begin{tabular}{|l|l|l|l|}
\hline Qualification & Number & Mean & Standard deviation \\
\hline Community college diploma & 27 & 3.06 & 0.43 \\
\hline Bachelor & 100 & 3.10 & 0.50 \\
\hline Other & 13 & 3.36 & 0.56 \\
\hline Total & 140 & 3.11 & 0.50 \\
\hline
\end{tabular}

Table (4) shows apparent variance in means and standard deviations of the degree to which organizational justice is practiced in commercial banks due to subjects educational qualification, so ANOVA test was performed to show the significance of these differences, and table (5) shows these results. 


\section{Macrothink}

Table 5. Results of ANOVA for educational qualification effect on respondents responses

\begin{tabular}{|l|l|l|l|l|l|}
\hline Source & Sum squares & DF & Mean squares & F & Sig \\
\hline Between groups & 0.879 & 2 & 0.439 & 1.785 & 0.172 \\
\hline Within groups & 33.721 & 137 & 0.246 & & \\
\hline Total & 34.600 & 139 & & & \\
\hline
\end{tabular}

Table (5) shows no statistically significant differences at $(\alpha=0.05)$ level due to subjects educational qualification, meaning that this hypothesis was accepted. Hypothesis(3) statistically significant differences at $(\alpha=0.05)$ in the degree to which organizational justice is practiced in commercial banks, from employees perspective and due to subjects total salary, will be found.

To test this hypothesis, means and standard deviations, according to subjects total salary, were computed and are displayed in table (6).

Table 6. Means and standard deviation for the effect of subjects total salary on their responses.

\begin{tabular}{|l|l|l|l|}
\hline Total salary & Number & Mean & S.D \\
\hline Less than 450 & 44 & 3.29 & 0.57 \\
\hline $450-650$ & 61 & 3.00 & 0.48 \\
\hline $650-850$ & 16 & 3.0 & 0.22 \\
\hline More than 850 & 19 & 3.17 & 0.47 \\
\hline Total & 140 & 3.11 & 0.50 \\
\hline
\end{tabular}

Table (6) shows apparent variance in means of the degree to which organizational justice in commercial banks from employees perspectives, due to their total salary, and to show significant differences between means, ANOVA test was performed, and table (7) displayed its results.

Table 7. ANOVA results for the effect of total salary on employees responses regarding organizational justice

\begin{tabular}{|l|l|l|l|l|l|}
\hline Source & & DF & Mean square & F & Sig \\
\hline Between groups & 2.372 & 3 & 0.791 & \multirow{3}{*}{3.337} & 0.021 \\
\cline { 1 - 4 } Within groups & 32.228 & 136 & 0.237 & & \\
\hline Total & 34.600 & 139 & & & \\
\hline
\end{tabular}

Table (7) shows significant differences at $(\alpha=0.05)$ level due to total salary, and to identify and show these differences, Schaffe post hoc comparisons were performed, and its results are shown in tale (8). 
Table 8. Schaffe comparison for the effect of subjects total salary

\begin{tabular}{|l|l|l|l|l|l|}
\hline Salary & Mean & 1 & 2 & 3 & 4 \\
\hline Less than $450(1)$ & 3.29 & & & & \\
\hline $450-650(2)$ & 3.00 & $* .29$ & & & \\
\hline $650-850(3)$ & 3.00 & 0.29 & 0.00 & & \\
\hline More than $850(4)$ & 3.17 & 0.11 & 0.17 & 0.17 & \\
\hline
\end{tabular}

* Significant at $(\alpha=0.05)$ level

Table (8) shows statistically significant differences at $(\alpha=0.05)$ level between salary category 450 - 650JDs and salary category less than $450 \mathrm{JDs}$, where differences were in favor of lower salary (less than 450 JDs.

Hypothesis four "No statistically significant relationship at $(\alpha=0.05)$ level in the degree to which organizational justice is practiced in commercial banks, due to subjects Job nature, will be found.

To test this hypothesis, means and standard deviations of respondents responses regarding the degree to which organizational justice is practiced in commercial banks due to subjects job nature, were used and to locates pair differences, $\mathrm{T}$ test was used, and results are shown in tale (9)

Tale 9. Results of t test for the effect of subjects job nature on their responses regarding organizational justice

\begin{tabular}{|l|l|l|l|l|l|l|}
\hline Job & Number & Mean & SD & T & DF & Sig \\
\hline Supervisory & 54 & 3.12 & 0.53 & 0.163 & 138 & 0.870 \\
\hline Non supervisory & 86 & 3.11 & 0.48 & & & \\
\hline
\end{tabular}

Table (9) shows no statistically significant differences at $(\alpha=0.05)$ due to job nature. So this hypothesis is accepted.

Hypothesis five, "Statistically significant differences at $(\alpha=0.05)$ level, in the degree to which organizational justice is practiced in commercial banks, due to subjects years of experience, will be fund.

To test this hypothesis, names and standard deviation of subjects responses, due to their years of experiences were used, and results are shown in tale (10).

Table 10. means and standard deviations of subjects responses according to their years of experience

\begin{tabular}{|l|l|l|l|}
\hline Years of experience & Number & Mean & SD \\
\hline Less than 5 & 31 & 3.33 & 0.60 \\
\hline $5-10$ & 45 & 3.03 & 0.46 \\
\hline $11-15$ & 30 & 3.20 & 0.43 \\
\hline More than 15 & 34 & 2.95 & 0.43 \\
\hline
\end{tabular}




\begin{tabular}{|l|l|l|l|}
\hline Total & 140 & 3.11 & 0.50 \\
\hline
\end{tabular}

Table (10) shows apparent variance between mean of respondents responses regarding the degree to which organizational justice is practiced, in commercial banks, due to their years of experiences and to locate the significant of these differences, ANOVA test was performed and results are shown in table (11).

Table 11. Results of ANOVA for the effect of subjects years of experience on their responses.

\begin{tabular}{|l|l|l|l|l|l|}
\hline Source & Sum squares & DF & Mean squares & F & Sig \\
\hline Between groups & 2.989 & 3 & 0.996 & 4.286 & 0.006 \\
\cline { 1 - 3 } Within groups & 31.611 & 136 & 0.232 & & \\
\cline { 1 - 3 } Total & 34.600 & 139 & & & \\
\hline
\end{tabular}

Table (11) shoes statistically significant differences at $(\alpha=0.05)$ level due to subject years of experience and to show pair differences, Schaffe post hoc comparisons were performed and results are shown in table 12.

table 12. Results of Shaffe's post hoc comparison for the effect of subjects years of experience on their responses.

\begin{tabular}{|l|l|c|c|c|c|}
\hline Years of experience & Mean & 1 & 2 & 3 & 4 \\
\hline Less than 5 (1) & 3.33 & & & & \\
\hline $5-10(2)$ & 3.03 & 0.30 & & & \\
\hline $11-15(3)$ & 3.20 & 0.13 & 0.17 & & \\
\hline More than 15 (4) & 2.95 & $* 0.95$ & 0.09 & 0.26 & \\
\hline
\end{tabular}

* significant at $(\alpha=0.05)$ level

Table (12) showed statistically significant difference at $(\alpha=0.05)$ between more than 15 years category and less than 5 years category in favor of loss than 5 . So, this hypothesis is accepted.

\section{Summary of Results}

After presentation, analyzing and testing hypotheses related to organizational structure and organizational justice adopted in Jordanian commercial banks to satisfy managers and employees need for achievement, some results were reached and can be summarized as follows:

1. One item of only was practiced with high degree, while other items were practiced with moderate degree, however total practice mean was also moderate.

2. Subject gender has no statistically significant effect.

3. Subjects educational qualification has no spastically significant effect.

4. Total salary has statistically significant difference.

5. Job nature has no statistically significant differences. 
6. Years of experience have statistically significant differences.

7. Organizational structure dimensions have no significant influence on employees in the banks, and this is consistent with the concept of need for achievement of individuals, which the individual does not look forward towards its achievement in the first place whether its related to levels of applying organizational structure components both centralization, formalization or others.

8. Organizational structure and organizational justice components, when combined together, have a significant influence in fulfilling employees needs for belonging.

9. Organizational structure and organizational justice, when combined, have no significant influence in fulfilling employees needs for independence.

10. Organizational structure and organizational justice, when combined together, have a statistically significant influence in fulfilling employees needs for power.

\section{Recommendations}

In height of the above results, researchers suggested the following recommendations:

1. Administrations of Jordanian commercial banks are to inform managers of all changes they make on organizational structure.

2. Top level management in these banks is to focus its attention on achieving fitness between organizational structure and organizational justice as this is one of the important means to improve work at banks.

3. The current study depended on certain number of organizational structure as well as on (schminek's 2000)theory on organizational justice, however researchers might use other organizational structure variable in future studies.

4. Commercial banks administrations are to increase their attention to organizational justice among bank employees.

5. The need for conducting more studies on the extent to which organizational structure influence organizational justice to make comparisons and contrasts between results.

6. Administrations should charity decisions related jobs in banks.

7. Taking employees personal demands into account when making decisions specific to curtain employees jobs.

8. Explaining rationales for decisions related to jobs.

9. Conducting more studies to enhance results generalizability.

\section{References}

Abu, Dhaim, Najat, Ibrahim, (2011). The role of human resources management practices in achieving organizational justices: from the standpoints departments heads in Jordanian ministries, unpublished Master thesis, business college, university of Jordan. 
AL- Ameri, Ahmad, (2003). Determinants and effects of organizational citizenship behavior in organizations, Journal of king Abdullaziz university, Economics and administrative series, 17(2), 67-83.

Al, Sound, R., \& Sultan, S. (2009). L the degrees of organizational justice among academic department chairs at Jordanian state universities and its relationship with faculty members organizational loyalty, Journal of Damascus university, 25(1-2).

Al-Ajmi, Rashid, (1998). Analysis of the relationship between organizational commitment (Loyalty) and workers feeling of organizational justice, Al- Idari, institute of public administration, Muscat, 71-91.

Al-Etewi, \& Amer. A. H. (2007). The effect of organizational justice in contextual performance in which correlation relationship, effect of performance level between organizational justice elements and contextual performance level of faculty members at administration college. University of Al-Qadisyah, Journal of the University Al-Qadisyah, $10(1)$.

Alkshali, Mahmoud, Harrim, Hussein, Shaker, Jaralla, (2006). The Impact of organizational structure dimensions on organizational knowledge generation: A Field Study of Jordanian Private Hospitals, Al-Zarqa for researches and studies, 8(1).

Al-Maitah, Ali, (2005) The degree to which, Jordanian public secondary schools principals, practice organizational justice and its relationship to their teachers organizational citizenship behaviors, unpublished $\mathrm{PhD}$, Amman Arabic university for graduate studies.

Al-Qatawneh. (2003). Influences of organizational Justices in organizational loyalty of employees working at administrative departments in Kerak, Tafillah and Ma'an Governorates. Unpublished Master thesis, Mutah university.

Al-Thaih, Salem Marswq, \& Ali, Hussien, (2003). Relationship between organizational structure and the extent to which organization justice is perceived, al-Idari, 94(25), 81-105.

Al-wadi, Rushdi, (2007). Organizational justice, a field study, Journal of modern commercial researches, 21(1).

Colquitt, J. A., Conlon, D. E., Wesson, M. J., Borter, O. L., \& Yeng, K. (2001). Justice at the millennium: A Mita -analytic review of 25 years of organizational justice research, Journal of applied psychology, 86, 425-44. https://doi.org/10.1037/0021-9010.86.3.425

Hammodeh, Abdel, Naser, (1999). Manager sensitivity to Justice and its relationship with relative importance of job returns ranking, Arab journal of administrative sciences, 6(2), 232258.

Hareem, Hussein, (1998). Organization's size and its influence in designing organizational structure of Jordanian private commercial banks organizations, Al - Idari, 23(84), 13-49.

Maharmeh, Thamer, (2000). The extent to which Jordanian public departments employees, at Kerak and Tafillah governorates, feel organizational justice, A field study, Journal of public 
administration, 319-340.

Schminke, Marshall, Ambrose, Maureen, L., \& Cropanzano, Russell, S. ( 2000). The effect of organizational structure on perceptions of procedural fairness. Journal of Applied Psychology, 85(2), 294-304. https://doi.org/10.1037/0021-9010.85.2.294

\section{Copyright Disclaimer}

Copyright for this article is retained by the author(s), with first publication rights granted to the journal.

This is an open-access article distributed under the terms and conditions of the Creative Commons Attribution license (http://creativecommons.org/licenses/by/3.0/). 